\title{
Stock Market Returns Under Macroeconomic Conditions: An Empirical Evidence from BRIC Economies
}

\author{
Rashid Naim Nasimi* Assad Naim Nasimi Maryyam Anwaar \\ Lahore School of Accountancy \& Finance, The University of Lahore, Islamabad, Pakistan
}

\begin{abstract}
Financial markets continuously incorporate information about macroeconomic events and monetary policy in order to make profitable investment decisions, and these are reflected in stock returns. In fact, financial markets have no perfect information, they do behave in forward looking manner, in that they monitor for new information that could affect the profitable investment decisions. The main objective of our paper is to explore the sensitivity of stock market returns to macroeconomic environments in Brazil, Russia, India, and China. In order to achieve the objective, the authors utilized data for major macroeconomic factors namely exchange rate, inflation rate, interest rate and oil price for the sample period starting from May 2007 to April 2017. We utilized OLS estimation technique to estimate the empirical models of our study. The findings of show no significant relationship between respective exchange rate, inflation rate, interest rate and oil price on market returns of either BRIC economy. However, the regression analysis reveals insignificant positive relationship of exchange rate, inflation rate and interest rate with stock market returns while oil prices has insignificant negative relationship. This suggests influence of other domestic and international macroeconomic factors on stock market returns. Furthermore, in the collective panel regression model of BRIC economies, we found that inflation rate has significant influence on stock market returns of BRIC economies. The findings of study help investors to know how specific stock performs to take profitable investment decision. It also assists policy makers to enhance and monitor monetary policy and helps managers in risk management.
\end{abstract}

Keywords: Macroeconomic indicators, Stock market returns, OLS

JEL classification: E31, E44, G1

DOI: $10.7176 / \mathrm{JESD} / 10-1-07$

\section{INTRODUCTION}

There are two major motivations for analyzing reaction of stock market returns to macroeconomic movements. First, it is important to understand what leads to the movements in stock market returns, in order to manage funds profitably. It helps the investors to know how specific stock performs. It provides clear idea of what macroeconomic events influence stock market indices. These indices are used as benchmark to evaluate performance of investments and the creation of financial instruments such as derivatives and options. Second, stock markets play as transmission mechanism for monetary policy, so understanding of the relationship between macroeconomics and stock market returns assist policy makers to enhance and monitor monetary policy. It also serves as a transmission mechanism upon which savings are mobilized and adequately distributed across the economic sectors with the view to realize inclusive growth. In addition to the foregoing stock market performance the following functions: it boosts investors' confidence in both financial institutions and even the entire economy; it indicates strength and viability of the productive sectors; and it facilitates capital allocation, investment and provides firms with ease avenue to have access to adequate and needed capital.

The macroeconomists and finance theorists agree that stock market values are acquired by the fundamentals of an economy which are recognized as macroeconomic conditions. In finance, one of the important theory known as Arbitrage Pricing Theory (henceforth, APT) developed by Ross (1976) as a means for relating the changes in returns on investments to unanticipated changes in a range of key value drivers for these investments [see, Kettell (2001)]. Under the framework of APT, all investments have expected returns and are affected by macroeconomic forces. Initially, the theory does not specify the range of these factors. APT suggests that the systematic dynamics which effect stock market returns are the macroeconomic variables. APT started with the assumption that stock returns are related to unknown number of unknown factors [see, Alexander et al. (2001)]. However, Roll and Ross (1980) identified four major factors which are the unanticipated changes in inflation, structure of interest rates, risk premiums, and the industrial production. However, a gap remains there between the theoretical importance of these factors and our sheer ignorance for their identification. The theory itself has not declared that among macroeconomic variables, which factors are most expected to effect the stock values, which means there is no such guidance available on selection of an appropriate macroeconomic factors.

The term emerging markets are used for those upcoming frontier nations with economic growth that transformed into explosive returns for investors. In the year 2001, Goldman Sach Economist Jim first cited the Brazil, Russia, India and China grouped as BRIC countries in his article entitled "The World Needs Better Economic BRIC". The Brazil, Russia, India and China economies collectively known as BRIC (henceforth, BRIC) has ever went on to encounter and to find out prospects of collaboration in investment, infrastructure 
development, trade and many more fields or areas.

Many researchers have observed the influence of macroeconomic dynamics on returns of stock, attaining proof from numerous stock exchanges around the world. More or less of the investigators have established significant positive result, some have established the negative significant result and few set up insignificant result of macroeconomic factors on returns of stock by taking two or three explanatory variables. Therefore, the problematic matter is existent there that what should be the real influence of macroeconomic indicators on stock returns. For this reason, the current study has increased the number of explanatory variables for the improved outcomes. Specifically, we aim to find out the answer to the below mentioned question:

$>$ Do macroeconomic factors have influence on stock market returns in BRIC?

Our study has vast significance for investors to know the macroeconomic factors that influences stock market returns. In this way, they can proactively take steps to control the risk that is innate due to the macroeconomic fluctuations. Furthermore, the asset pricing model and arbitrage pricing theory suggests that macroeconomic factors are of enormous importance to investors and the policy makers. Also, although there are plenty of studies on the effect of macroeconomic factors on market returns, this study will add to the literature by providing the perfect image of BRIC economies by means of specific macroeconomic factors.

\section{LITERATURE REVIEW}

2.1 Empirical literature

In the last two decades, numerous financial analysts, researchers, and experts have tried to forecast the association between macroeconomic variables and stock returns. They have performed empirical analysis to inspect the influence of macroeconomic variables on stock returns.

Ta and Toe (1985) in their empirical analysis revealed that macroeconomic factors and stock returns were extremely interrelated to each other in Singapore. Chen et al. (1986) linked the stock market returns in the United States (US) to a rectilinear purpose of macroeconomic factors by using APT model and established that there is a strong correlation among US stock market and selected macroeconomic variables. Bahmani and Payesteh (1993) showed that two-way causality exists among stock prices and exchange rate in short-run. Bhattacharya and Chakravarty (1994) studied the performance of stock price in relative to macroeconomic variables in India for the year 1992. They findings revealed that behavior of stock price is disparate to macroeconomic variables. Fang and Loo (1994) studied the relationship between stock returns and international trade. The findings provided the indication in approval of the efficient market hypothesis. Further, their empirical outcomes constructed on vector autoregressive model (VAR) recommended that stock returns are determined by international trade.

Robert (2008) aimed to explore the relationship amongst stock market returns and macroeconomic variables namely consumer price index (CPI), money supply, foreign exchange rate, gross domestic product and oil price in BRIC for period during 1999 to 2006. The researcher has used Box Jenkin's (ARIMA) model. The results showed that exchange rate and oil price have no significant impact on the stock market returns in BRIC. Maku and Atanda (2009) scrutinized the effect of macroeconomic variables on stock market returns in Nigeria for the period during 1984 to 2007 . The macroeconomic variables included in study are inflation rate, exchange rate, money supply and real output. The findings of the study revealed that stock market returns in Nigeria is determined by macroeconomic variables. Aisyah, Noor and Fauziah (2009) examined the effect of money supply, interest rate, industrial productivity index and reserves on Malaysian Stock Index returns using VAR model. The findings confirms that stock market returns are significantly influenced by the macroeconomic variables used in the study.

Quadir (2012) studied the impact of macroeconomic variables on stock returns of Dhaka Stock Exchange for the period during 2000 to 2007. The findings of the study showed positive effect of interest rate, industrial production and Treasury bill on stock market returns. Samadi et al. (2012) examined the association of macroeconomic indicators and stock returns in Tehran Stock Exchange for period during 1379 to 1389 . The study utilized macroeconomic variables such as exchange rate, world gold price, inflation, liquidity and oil price. The findings of the study revealed that macroeconomic variables have no influence on stock returns while liquidity has high significant effect on stock returns. Nkechukwu, Onyeagba and Okoh (2013) aimed to assess the effect of GDP and broad money supply on prices of the stock market in Nigeria during 1980 to 2013. The findings indicated that Nigerian stock market has long-term relationship with the macroeconomic variables.

Alam and Rashid (2014) examined the effect of inflation rate, industrial production, exchange rate, money supply and interest rate on market returns of Karachi Stock Exchange (KSE) by using GARCH model. The findings revealed that the industrial production index has positive influence on returns, whereas, inflation, exchange rate, interest rate and money supply showed negative influence on market returns of KSE-100 index. Zaigham (2014) examined the effect of industrial production index, risk free rates, CPI, money supply on stock returns of firms listed at KSE for period during 2001 to 2011. The findings of the study showed that CPI, money supply, and risk free rate have negative impact on stock returns of firms listed at KSE. However, industrial 
production index showed positive impact on the returns of the firms. Lechman and Marszk (2015) studied the impact of macroeconomic variables on BRIC economies for the period during 2002 to 2012. The findings of the showed high statistical significant impact of macroeconomic variables on stock market returns in Brazil and India. However, weak significant impact of macroeconomic variables on stock market returns in Russia and China were revealed.

Jareno and Negrut (2016) examined the relationship among macroeconomic factors (gross domestic product (GDP), CPI, industrial productivity index, unemployment rate, long term interest rate) and US share market. The findings of the study showed that these macroeconomic variables have significant impact on US stock market with exception of consumer price index. Mughambi and Oketch (2016) explored the effect of macroeconomic variables (exchange rate, inflation, interest rate and GDP) on stock returns of commercial banks listed at Kenya Stock Exchange for period during 2000 to 2015. The findings of the study showed that exchange rate, interest rate and inflation have significant effect on stock returns while GDP has an insignificant impact.

Nasimi, Nasimi and Khurshid (2018) studied the impact of macroeconomic and political instabilities on stock returns in UK. The study panel data consists of 23 manufacturing firms listed at London Stock Exchange (LSE) during the period 2005 to 2016. The authors utilized two-step system GMM to estimate the multivariate panel regression model that incorporated stock returns as dependent variable and explanatory variables such as measures of political instability and macroeconomic uncertainty. The findings of the study revealed the significant impact of political and macroeconomic uncertainty on stock returns in UK. However, the influence of macroeconomic uncertainty on stock returns is pronounced higher than the effect of political uncertainty on stock returns.

\subsection{Development of Hypothesis}

In this section, based on the findings reported by the most relevant empirical literatures, we develop the hypotheses for our study.

\subsubsection{Exchange rate}

Exchange rate stability and stock market growth are the two economic aims that every economy desires to achieve. However, it is merely because of the fact that the financial position of every economy whether it is developed or developing can be gauged from stability in its exchange rate. A very strong exchange rate is a signal that demonstrates strength and viability of an economy [see, Hassan et al. (2017)]. Contrary, a very weak currency exchange rate is reflection of vulnerable and fragile economy. According to Sani and Hassan (2018), the exchange rate instability has real economic shocks because it adversely affects the prices level, firms' profits and also the entire activity in an economy. Moreover, the exchange rate instability may bring about uncertainties for the investors. Thus, exchange rate plays as an important determinant for the stock market fluctuations [see, Khan and Ali (2015)].

Empirical studies such as Asaola and Ogunmuyiwa (2011), and Lawal and Ijirshar (2013) revealed unidirectional causality running from the exchange rate to stock market returns. Though, Zubair (2013) revealed that there is no evidence of causality between exchange rate and stock market prices. Therefore, based on the above discussion, we propose the below hypothesis that foreign exchange rate has influencing power on stock market returns.

Hypothesis 1: There is a significant impact of foreign exchange rate on stock market returns.

2.2.2 Inflation rate

There is a large body of literature regarding inflation and stock market returns. Although there are substantial debates on the nature- positive versus negative; linearity versus non-linearity, causality and magnitude of the inflation-returns relationship, most researchers believe that high and variable inflation is detrimental to economic growth. Hussein and Mgammal (2012) examined the relationship among the inflation, interest rate, and stock market prices in Kingdom of Saudi Arabia and United Arab Emirate (UAE) using monthly data from 2008:1 to 2009:12. The study reveals that exchange rate is negatively related to stock market prices while no evidence of relationship exists between interest and inflation. On the other hand, Yaya and Shittu (2010) proved that inflation exerts significant influence on conditional stock market volatility within the Nigerian economy. Based on the above debate, we propose the that inflation has significant influence on stock market returns.

Hypothesis 2: There is a significant impact of inflation rate on stock market returns.

2.2.3 Interest rate

In valuation of stocks prices, investors consider the macroeconomic variables. These variables affect the performance of the stock markets. Interest rate, exchange rate and inflation are very significant among these macroeconomic variables. A large strand of empirical literature is present on the topic. Asaolu and Ogunmuyiwa (2011) tested whether macroeconomic variables exert positive impact or otherwise on the stock market movement. The findings showed that among macroeconomic variables there is unidirectional causality running from exchange rate to average share price. Hussein and Mgammal (2012) revealed that there is no evidence of relationship exists between interest and stock returns. On the other hand, Osamwonyi and Osagie (2012) found 
that among macroeconomic variables, interest rate affect stock market index. Interest rate is inversely related to stock prices. An increase in interest rate causes decrease in stock prices because required rate of return on stocks rises which causes decrease in stock prices. From the above debate, we propose the that interest rate has significant influence on the stock market returns.

Hypothesis 3: There is a significant impact of interest rate on stock market returns.

2.2.4 Oil price

The channel through which oil prices affect the stock market returns merely depends on how an economy is affected by change in the oil prices. Sadorsky (2001) used a multifactor model for assessing the relationship between oil prices and stock returns. He found strong positive effects of oil prices for Canadian oil and gas sector returns. Some recent studies have examined the crisis period and the links between major stocks and oil markets. For instance, Filis et al. (2011), who used monthly oil prices and major stock market indices of three oil-exporting countries namely Canada, Mexico, and Brazil and three oil-importing countries including US, Germany and the Netherlands. They found that lagged correlation showed that oil prices have a negative effect in all stock markets, regardless of the origin of the shock, with the only exception being the 2008 global financial crisis. Hence, we propose oil price has significant power for the stock market returns.

Hypothesis 4: There is a significant impact of oil price on stock market returns.

\section{RESEARCH METHODOLOGY}

This section provides an illustration on research methodology. Research methodology refers to the systematic way of solving problems and provides work plan. In other words, we can define it is an organized system of problem solving techniques.

\subsection{Empirical Models}

The major purpose of our study is to identify the macroeconomic factors that have explanatory power for stock market returns of BRIC economies. For achieving this purpose, we primarily establish an empirical model named as simple regression model which represented in equation (1). This empirical model analyzes the impact of macroeconomic indicators on stock market returns for each of BRIC economies individually. Next, we establish an empirical model, named as panel regression model. It estimates the relationship between macroeconomic indicators and stock market returns for BRIC economies jointly. The panel regression model for the $i^{\text {th }}$ cross-section and at time $t$ is represented in equation (2).

$$
R_{S M_{t}}=\beta_{0}+\beta_{1} F E R_{t}+\beta_{2} I N F_{t}+\beta_{3} I R_{t}+\beta_{4} O P_{t}+\varepsilon_{t}
$$

where $R_{S M_{t}}$ is stock market return at time $t$. FER $\mathrm{t}_{\mathrm{t}}$ denotes foreign exchange rate at time $t$. INF $\mathrm{I}_{\mathrm{t}}$ is inflation rate at time $t$. $\mathrm{IR}_{\mathrm{t}}$ symbolizes interest rate at time $t$. Similarly, $\mathrm{OP}_{\mathrm{t}}$ indicates oil price at time $t . \beta_{0}$ is coefficient of intercept which is a constant. $\beta_{1}-\beta_{4}$ indicates the coefficients of slope. $\varepsilon_{\mathrm{t}}$ is the error term.

$$
R_{S M_{i t}}=\beta_{0}+\beta_{1} F E R_{i t}+\beta_{2} I N F_{i t}+\beta_{3} I R_{i t}+\beta_{4} O P_{i t}+f_{i}+f_{t}+\varepsilon_{i t}
$$

where $R_{S M_{i t}}$ is stock market return of the $i^{\text {th }}$ cross-section at time $t . \mathrm{FER}_{\mathrm{it}}$ is foreign exchange rate of $i^{\text {th }}$ cross-section at time $t . \mathrm{INF}_{\mathrm{it}}$ is inflation rate of the $i^{\text {th }}$ cross-section at time $t . \mathrm{IR}_{\mathrm{it}}$ symbolizes interest rate of $i^{\text {th }}$ cross-section at time $t$. Similarly, $\mathrm{OP}_{\text {it }}$ indicates oil price of the $i^{\text {th }}$ cross-section at time $t . f_{i}$ and $f_{t}$ represents the cross-section-fixed and time-fixed effects, respectively.

\subsection{Data and estimation technique}

The main objective of our study is to empirically analyze the influence of macroeconomic conditions on stock market returns in BRIC economies. For this purpose, we use data on key macroeconomic indicators namely exchange rate, inflation rate, interest rate and oil price. The panel data is constructed on the monthly basis data for period of 10 years covering May 2007 to April 2017. We employed ordinary least squares (OLS) method to estimate the empirical models. Panel regression analysis is a statistical measure that determines the relationship between dependent and explanatory variables ${ }^{[1]}$. It helps to understand the change in dependent variable to change in independent variables. Also, it consists of three major effect models which are common effect, fixed effect and random effect models ${ }^{[2]}$. In order to choose the best effect model for our study, we employ the Likelihood Ratio Test and Hausman Test, see notes ${ }^{[3]}$ and ${ }^{[4]}$ respectively.

\subsection{Study variables}

\subsubsection{Stock Market Return}

The dependent variable means a variable that derives its values from other (explanatory) variables. In our study, we used the stock market returns as dependent variable in the regression model. Stock market returns show the returns of a market index at a point in time as a whole. We calculated the stock market return as follows:

$$
R_{S M}=\frac{\left(P_{t}-P_{o}\right)}{P_{o}}
$$


where $\mathrm{P}_{\mathrm{o}}$ is the initial market price and $\mathrm{P}_{\mathrm{t}}$ is the ending market price.

3.3.2 Foreign Exchange Rate

Foreign exchange rate, alternately known as the Forex rate, can be defined as the value of currency of one country with respect to the currency of the other country. We calculated the exchange rate as:

$$
F E R=\frac{\text { Difference between two exchange rates }}{\text { Market exchange rate }} \times 100
$$

\subsubsection{Interest Rate}

A rate which is charged or paid for the use of money is known as interest rate. The amount charged by lender as a percentage of principal to the borrower for use of assets is called interest rate. Interest rate is calculated as:

$$
A_{(\text {Total Amout })}=P(1+r t)
$$

where $\mathrm{A}_{\text {(Total Amount) }}$ is the total accrued amount (that is, the principal amount plus interest). $\mathrm{P}$ indicates the principal amount. $r$ is the rate of interest. $t$ shows the time period in months or years.

3.3.4 Inflation rate

The sustained rise in the over-all prices of goods and services in a country during a period of time is identified as inflation. The rate at which the purchasing power of currency falls due to rising of price-levels for goods and services is known as inflation rate. Inflation rate is measured by:

$$
I N F_{t}=C P I_{t}-C P I_{(t-12)}
$$

where $C P I_{t}$ is the inflation (that is, consumer price index) in month $t . C P I_{(t-12)}$ is the CPI in the similar month of the preceding year.

3.3.5 Oil Price

Oil price is the spot price of a barrel of benchmark crude oil most commonly either the West Texas Intermediate or the Brent Blend.

$$
\text { One } \text { barrel }_{(\mathrm{Oil})}=42 \text { Gallons }=159 \text { Litres }
$$

The oil price for each of the BRIC economies is calculated using the below formula:

Oil Price $=$ Spot Price (in USD) $x$ Exchange rate

\section{RESULTS AND DISCUSSIONS}

\subsection{Descriptive Analysis}

Descriptive analysis presents the summary statistics that expresses the characteristic of data [see, Anwaar (2016), and Nasimi (2016)]. Table I presents the descriptive statistics of our study. It presents mean, standard deviation, minimum and maximum values. According to normal distribution features, at least 68 percent of observations fall within a range of +1 and -1 standard deviation from mean [see, Chechet and Olayiwola (2014)]. However, standard deviation that falls out of the range -1 and +1 falls within the range of -2 and +2 and that distribution has relative frequency about 5 percent (that is, 95 percent of this distribution falls within the range of -2 and +2 ). Moreover, maximum and minimum values are used to determine the outliers present in data. Hence, we can say that all of the variables are normally distributed.

On observing the descriptive results for Brazil, we found that oil price has the highest mean value of 39.1131 with a minimum and maximum values of 8.3100 and 86.5212 , respectively. It also shows a standard deviation of 17.5817 which implies that $175.817 \%$ of the data is spread around the mean value. However, stock market returns showed lowest mean value of 0.0046 with minimum value of -0.2480 and maximum value of 0.1697. It shows a standard deviation of 0.0664 which implies that $6.64 \%$ of the data is spread around the mean value. Similarly, in the descriptive results for Russia, we found that inflation rate has highest mean value of 9.5750 with a minimum and maximum values of 3.8640 and 21.6224 , respectively. It also shows a standard deviation of 4.1620 which implies that $416.20 \%$ of the data is spread around the mean value. However, stock market returns shows a lowest mean value of 0.0006 with minimum value of -0.3618 and maximum value of 0.3058 . It shows a standard deviation of 0.1015 which implies that $10.15 \%$ of the data is spread around the mean value. In the context of Indian data, inflation rate has the highest mean value of 8.6127 with a minimum and maximum values of 2.8423 and 14.2113, respectively. It also shows a standard deviation of 2.6894 which implies that $268.94 \%$ of the data is spread around the mean value. However, stock market returns shows a lowest mean value of 0.0100 with minimum value of -0.2597 and maximum value of 0.3129 . It shows a standard deviation of 0.0716 which implies that $7.16 \%$ of the data is spread around the mean value. On looking at the data set on China, we can observe oil price has the highest mean value of 12.0579 with a minimum and maximum values of 5.1141 and 20.2946, respectively. It also shows a standard deviation of 3.7312 which implies that $373.12 \%$ of the data is spread around the mean value. However, stock market returns shows lowest mean value of 0.0018 with minimum value of -0.2463 and maximum value of 0.2057 . It shows a standard deviation of 0.0857 which implies that $8.57 \%$ of the data is spread around the mean value. 


\subsection{Panel descriptive statistics of BRIC}

Table II presents the panel descriptive statistics of BRIC economies collectively. We can see that it also presents the values for skewness and kurtosis. Skewness shows the extent to which data are not symmetrical. Kurtosis determines how tail and the peak of a distribution differs from normal distribution. A kurtosis value of 0 indicates that the data follow the normal distribution perfectly. A kurtosis value that significantly deviates from 0 indicates that the data are not normally distributed.

Table II Panel descriptive statistics of BRIC economies

\begin{tabular}{lccccc}
\hline \hline & SR & EXR & INF & IR & OP \\
\hline \hline Mean & 0.0047 & 0.1675 & 0.0698 & 0.0759 & 13.737 \\
Median & 0.0066 & 0.0866 & 0.0682 & 0.0762 & 5.3403 \\
Maximum & 0.3129 & 0.6395 & 0.2162 & 0.1700 & 86.521 \\
Minimum & -0.3618 & 0.0129 & -0.0175 & 0.0279 & 0.4371 \\
Std. Dev. & 0.0826 & 0.1905 & 0.0395 & 0.0346 & 17.605 \\
Skewness & -0.2280 & 1.1623 & 0.8223 & 0.2382 & 1.6452 \\
Kurtosis & 5.0077 & 2.9382 & 4.7097 & 2.0517 & 4.7976 \\
Observations & 480 & 480 & 480 & 480 & 480 \\
\hline \hline
\end{tabular}

\subsection{Correlation Analysis}

Correlation represents the linear relationship among variables. The correlation analysis shows strength and direction of association [see, Nasimi (2016)]. The most relevant measure of correlation is Pearson's correlation coefficient [see, Nasimi, Nasimi and Basit (2018)]. It ranges between +1 and -1 . However, +1 shows the perfect positive correlation among variables, where, -1 shows perfect negative association exists. And 0 means there is no linear association among variables. Moreover, correlation analysis helps in identifying multicollinearity problems among variables. Table III shows the correlation matrix for all variables.

Table III Correlation analysis for BRIC economies individually

\begin{tabular}{lccccc}
\hline \multicolumn{1}{c}{ Variables } & Codes & Brazil & Russia & India & China \\
\hline \hline Exchange Rate & FER & -0.0703 & -0.1013 & -0.0177 & 0.0378 \\
Inflation Rate & INF & -0.0368 & -0.0240 & -0.0544 & -0.2753 \\
Interest Rate & IR & -0.0497 & 0.0180 & 0.0149 & -0.2452 \\
Oil Prices & OP & -0.1182 & -0.0869 & -0.0756 & -0.2112 \\
\hline \hline
\end{tabular}

From the table, we can observe that all variables have shown negative coefficients with the market returns of Brazil However, we can see all variables have also shown negative coefficients with the market returns of Russia, India, and China with the exception of interest rate. This shows the preliminary evidence of negative impact of macroeconomic variables on stock market returns of the economies.

\subsection{Panel correlation of BRIC}

Table IV presents the correlation analysis for BRIC panel. We can see negative correlation coefficients of exchange rate, inflation rate, and oil prices with stock market returns and positive coefficient of interest rate with stock market return. Further, we can see that inflation has a negative coefficient with exchange rate while interest rate and oil prices have shown positive coefficients with exchange rate. Next, we see that interest rate has a positive coefficient with inflation rate while oil price has a negative coefficient. Lastly, we see that oil price and interest rates are positively correlated with each other. Additionally, we observe that problem of multicollinearity ${ }^{[5]}$ does not seem be present in our study variables.

Table IV Panel correlation analysis of BRIC

\begin{tabular}{|c|c|c|c|c|c|}
\hline & RM & $\begin{array}{l}\text { EXR } \\
\end{array}$ & INF & IR & OP \\
\hline $\mathbf{R M}$ & 1.0000 & & & & \\
\hline EXR & -0.0169 & 1.0000 & & & \\
\hline INF & -0.0516 & -0.2760 & 1.0000 & & \\
\hline IR & 0.0015 & 0.3447 & 0.6069 & 1.0000 & \\
\hline OP & -0.0442 & 0.9542 & -0.2654 & 0.2891 & 1.0000 \\
\hline
\end{tabular}

4.5 Regression analysis

Regression analysis investigates the dependency of dependent variable on explanatory variables. It measures the change in dependent variable to change in explanatory variables. Precisely, it measures values of increase/decrease in dependent variable when explanatory variables are varied [see, Nasimi and Nasimi (2018)]. 


\subsubsection{Panel regression for each BRIC economy}

Table V shows the results of panel regression for each BRIC economy. Regression analysis reveals the change in dependent variable to change in independent variables [also, see Nasimi, Nasimi and Khurshid (2018)]. On observing the table, we can see that all macroeconomic measures have insignificant negative impact on stock market returns in Brazil. On observing the results for Russia, we see that exchange rate and inflation have insignificant negative impact on stock market returns whereas interest rate and oil prices have insignificant positive influence. While, in India, inflation rate and oil prices have negative impact on stock market returns while exchange rate and interest rate have insignificant influence. Looking at the results for China, we see that exchange rate has insignificant positive impact on stock market returns while other macroeconomic variables such as inflation rate, interest rate, and oil prices have insignificant impact on stock market returns. Overall, we see that all macroeconomic variables have insignificant impact on stock market returns of each individual economy. The findings of our study is in consistent to Robert (2008) and Samadi et al. (2012) who found no significant impact of macroeconomic variables on stock returns. This implies that existence of other domestic and international factors that have influence on the stock markets of BRIC economies. These factors may include political instability, firm-uncertainty, and other influencing factors that prevails in the markets of these economies.

4.5.2 Panel Regression for BRIC

Table VI shows the Likelihood ratio for selecting the appropriate effect model. The value of cross section $\mathrm{F}$ with prob. value of 0.6632 shows that common effect is the best fit for the study. Table VII shows the coefficients of panel regression results. It is observed that the exchange rate has a positive coefficient of 0.0659 with the p-value of 0.3735 . This shows insignificant positive association exists between exchange rate and stock market returns. Inflation rate has a negative coefficient of 0.3166 with the p-value of 0.0454 . It implies the significant negative relationship of inflation rate and stock market returns. One standard increase in inflation rate will decrease stock market returns by 0.3166 standard deviation on average. This negative association among inflation rate and stock market returns implies that short term investors sell their stocks in order gain benefits from the increased prices due to inflation, this in turn increases the supply of stock in market and decreases the stock prices. Ultimately, this decrease in prices are reflected into the stock returns. Moreover, our finding supports the empirical results of Roll and Ross (1980). On the other hand, interest rate has a positive coefficient of 0.2813 with the p-value of 0.1360 . It shows the insignificant positive association of interest rate and stock market returns. Lastly, we can see that oil price has a negative coefficient of 0.0012 with the $p$-value of 0.0912 . It implies that insignificant negative relationship exists between oil price and stock market returns/

The coefficient of determination, R-squared, has value of 0.1272 which shows that $12.72 \%$ deviation in stock market returns has been described by the explanatory variables. The value of $\operatorname{Adj}^{2}$ of 0.0901 which means that if one more relevant variable is incorporated in the model of the study, then the value of R-squared adjusts by $9.0173 \%$. However, F-statistics show the fitness of our study models.

Table VII Panel Regression for BRIC

\begin{tabular}{crrrr}
\hline \hline Variable & Coefficient & Std. Error & t-Statistic & Prob. \\
\hline \hline C & 0.0114 & 0.0096 & 1.1897 & 0.2347 \\
EXR & 0.0659 & 0.0740 & 0.8907 & 0.3735 \\
INF & -0.3166 & 0.1593 & -1.9876 & 0.0454 \\
INT & 0.2813 & 0.1884 & 1.4933 & 0.1360 \\
OP & -0.0012 & 0.0007 & -1.6927 & 0.0912 \\
\hline \hline R-squared & 0.1272 & & & \\
Adjusted R-squared & 0.0901 & & & \\
F-statistic & 5.0895 & & & \\
Prob(F-statistic) & 0.0210 & & & \\
\hline \hline
\end{tabular}

\section{CONCLUSION}

\subsection{Conclusion}

The current study aims to examine the effect of macroeconomic variables on stock market returns in BRIC economies. We used monthly data over the period May 2007 to April 2017. The multivariate empirical model of our study consists of a dependent variable, that is, stock market returns. However, the explanatory variables included are interest rate, exchange rate, oil price and inflation rate. We utilized OLS estimation method to estimate empirical models.

The results from the individual economy showed that the explanatory variables have insignificant impact on market returns in each BRIC economy. However, the panel results exhibited that exchange rate and interest rate has insignificant positive effect on market returns. Oil price has insignificant negative effect on market returns. 
However, inflation rate has a significant negative effect on market returns; and hence, is in line with the findings of Roll and Ross (1980). This negative association implies that investors sell their stocks in order gain benefits from the increased prices in short-run, the supply of stock increases in market and thus decreases the stock prices. These results showed weak explanatory power based on findings. This shows that there are other factors affecting stock market returns in BRIC economies. Further, it reveals that these four emerging economies are unresponsive to fluctuations in these macroeconomic indicators. The findings of study help investors to know how specific stock performs to take profitable investment decision. It also assists policy makers to enhance and monitor monetary policy and helps managers in risk management.

\subsection{Recommendations}

We recommend the policymakers to ensure effective implementation of monetary and fiscal policy instruments and device strong way of harmonizing monetary and fiscal policies in order to maintain stable economy and avoid structural break that affect the whole system including the stock market. We recommend the future researchers to incorporate more macroeconomic variables and analyze the effect of macroeconomic variables on stock market returns in developed and developing economies, to reveal how differently macroeconomic events affect the returns in developed and developing economies.

\section{NOTES:}

[1] The word explanatory variables and independent variables are used interchangeably, see Gujarati and Porter (2009).

[2] In common effect model, the key assumption for the data is that the coefficient of intercept is constant for all the cross-sections. However, fixed effect model has an assumption that the coefficient of intercept is group specific. Further, random effect model states the coefficient of intercept varies across the cross-sections.

[3] In panel data model, Likelihood Ratio Test is applied to distinguish between common effects model and fixed effects model. In this case, Likelihood Ratio Test has below hypothesis:

$\mathrm{H}_{0}$ : Common Effect is preferred due to higher efficiency.

$\mathrm{H}_{1}$ : Fixed Effect is preferred as least consistent.

[4] In the panel data model, Hausman Test is applied to distinguish between fixed effects model and random effects model. In this case, Hausman Test has below hypothesis:

$\mathrm{H}_{0}$ : Random Effect is preferred due to higher efficiency.

$\mathrm{H}_{1}$ : Fixed Effect is preferred as least consistent.

[5] The problems of multicollinearity occurs for the coefficients of correlation at the threshold of 0.80 and 0.90 (Gujarati, 2003).

\section{REFERENCES}

Aisyah, A.R., Noor, Z.M.S. \& Fauziah, H.T. (2009). Macroeconomic Determinants of Malaysian Stock Market. African Journal of Business Management, 3(3), 95-106

Alam, Z., \& Rashid, K. (2014). Time Series Analysis of the Relationship between Macroeconomic Factors and the Stock Market Returns in Pakistan. Journal of Yasar University, 9(36), 6261-6380

Alexander, G.J., Sharpe, W.F. \& Bailey, J.V. (2001), Fundamentals of Investments, 3rd ed. Prentice-Hall, Englewood Cliffs, NJ.

Anwaar, M. (2016). Impact of Firms Performance on Stock Returns (Evidence from Listed Companies of FTSE100 Index London, UK). Global Journal of Management and Business Research, 16(1), 31-39

Asaolu T.O. \& Ogunmuyiwa, MS. (2011). An econometric analysis of the impact of macroeconomic variables on stock market movement in Nigeria. Asian Journal of Business Management, 3, 72-78

Bhattacharya, B.B. \& Chakravarty, S. (1994). Share price behaviour in India: An Econometric Analysis, paper presented in Econometric Conference, Pune

Bahmani-Oskooee, M., \& Payesteh, S. (1993). Budget deficits and the value of the dollar: an application of cointegration and error-correction modeling. Journal of Macroeconomics, 15(4), 661-677.

Chen, N. F., Roll, R., \& Ross, S. A. (1986). Economic forces and the stock market. Journal of Business, 59(3), 383-403

Fang, H \& J. Loo (1994). Dollar value and stock returns. International review of economics and finance, 3(2), 222-231

Hussein, M. \& Mgammal, H. (2012). Effect of Inflation, Interest Rates and Exchange Rates on Stock Prices: Comparative Study among Two GCC Countries. International Journal of Finance and Accounting, 1, 179189

Jareno, F., \& Negrut, L. (2016). US Stock Market And Macroeconomic Factors. The Journal of Applied Business Research, 32(1), 325-340 
Lawal, M. \& Ijirshar, V. U. (2013). Empirical Analysis of Exchange Rate Volatility and Nigeria's Stock Market Performance. International Journal of Science and Research, 4,1592-1600

Lechman, E., \& Marszk, A. (2015). ICT technologies and financial innovations: the case of Exchange Traded Funds in Brazil, Japan, Mexico, South Korea and the United States. Technological Forecasting and Social Change, 99, 355-376.

Maku, O.E. \& Atanda, A.A. (2009). Does macroeconomic variables exert shock on the Nigerian Stock Exchange", Munich Personal RePEc Archive, Paper No. 17917.

Mugambi, M., \& Okech, T. C. (2016). Effect of macroeconomic variables on stock returns of listed commercial banks in kenya. International Journal of Economics, Commerce and Management, 7(6), 390-418

Nasimi, A.N. (2016). Effect of Capital Structure on Firm Profitability (An Empirical Evidence from London, UK). Global Journal of Management and Business: C. Finance, 16(4), 9-20

Nasimi, R.N. (2016). Determinants of Capital Structure: An Empirical Evidence from United States. Global Journal of Management and Business: C. Finance, 16(4), 29-42

Nasimi, A.N \& Nasimi, R.N (2018). Effect of Capital Structure on Firms' Profitability: An empirical evidence from Pakistan Stock Exchange (PSX). Research Journal of Finance and Accounting, 9(11), 57-68

Nasimi, R. N., Nasimi, A. N., \& Khurshid, S. (2018). Stock returns under political and macroeconomic instabilities: an empirical analysis from United Kingdom. Research Journal of Finance and Accounting, $9(15), 62-73$

Nasimi, A. N., Nasimi, R. N., \& Basit, R. A. (2018). Factors affecting e-commerce customer loyalty in Pakistan. Journal of Marketing and Consumer Research, 49, 17-30

Nkechukwu, G., Onyeagba, J., \& Okoh, J. (2013). Macroeconomic Variables and Stock Market Prices in Nigeria: A Cointegration and Vector Error Correction Model Tests. International Journal of Science and Research, 4(6), 717-724

Osamwonyi, I.O. \& Osagie, EI. (2012) The Relationship between Macroeconomic Variables Stock Market Index in Nigeria. J Economics 3: 55-63

Quadir, M. M. (2012). The Effect of Macroeconomic Variables On Stock Returns on Dhaka Stock Exchange. International Journal of Economics and Financial Issues, 2(4), 480 - 487.

Robert, D. J. (2008). Effect Of Macroeconomic Variables On Stock Market Returns For Four Emerging Economies: Brazil, Russia, India, And China. International Business \& Economics Research Journal, 7(3), $1-8$.

Roll, R. and Ross, S.A. (1980), "An empirical investigation of the arbitrage pricing theory", Journal of Finance, Vol. 35 No. 5, pp. 1073-103.

Ross, S.A. (1976), "The arbitrage pricing theory of capital assets pricing", Journal of Economic Theory, Vol. 13, pp. 341-60.

Samadi, S., Bayani, O., \& Ghalandari, M. (June 2012). The Relationship between Macroeconomic Variables and Stock Returns in the Tehran Stock Exchange. International Journal of Academic Research in Business and Social Sciences, 2(6), 559 - 573

Ta, H. P. \& Teo, C. L. 1985. Portfolio diversification across industry sectors. Securities Industry Review 11(2): 33-39.

Yaya, OS. \& Shittu, OI. (2010). On the Impact of Inflation and Exchange Rate on Conditional Stock Market Volatility in Nigeria: A Re-assessment. American Journal of Scientific and Industrial Research, 1, 115-117

Zaighum, I. (2014). Impact of macroeconomic factors on non-financial firms stock returns: Evidence from sectorial study of KSE-100 index. Journal of Management Sciences, 1(1), 35-48.

Zubair, A. (2013). Causal Relationship between Stock Market Index and Exchange Rate: Evidence from Nigeria. CBN Journal of Applied Statistics, 4, 87-110 


\section{TABLES}

Table I Descriptive statistics for individual BRIC economy

\begin{tabular}{|c|c|c|c|c|}
\hline Variables & Mean & Std. Dev. & Minimum & Maximum \\
\hline & \multicolumn{4}{|c|}{ BRAZIL } \\
\hline Market Returns & 0.0046 & 0.0664 & -0.2480 & 0.1697 \\
\hline Exchange Rate & 0.470471 & 0.1113 & 0.2472 & 0.6395 \\
\hline Inflation Rate & 6.916702 & 2.8298 & 2.6367 & 14.1285 \\
\hline Interest Rate & 0.111629 & 0.0208 & 0.073 & 0.1425 \\
\hline \multirow[t]{2}{*}{ Oil Prices } & 39.1131 & 17.5817 & 8.3100 & 86.5212 \\
\hline & \multicolumn{4}{|c|}{ RUSSIA } \\
\hline Market Returns & 0.0006 & 0.1015 & -0.3618 & 0.3058 \\
\hline Exchange Rate & 0.0294 & 0.0084 & 0.0130 & 0.0428 \\
\hline Inflation Rate & 9.5750 & 4.1620 & 3.8640 & 21.6224 \\
\hline Interest Rate & 0.0877 & 0.0283 & 0.0525 & 0.1700 \\
\hline \multirow[t]{2}{*}{ Oil Prices } & 2.4712 & 1.1923 & 0.4371 & 5.9228 \\
\hline & \multicolumn{4}{|c|}{ INDIA } \\
\hline Market Returns & 0.0100 & 0.0716 & -0.2597 & 0.3129 \\
\hline Exchange Rate & 0.0192 & 0.0033 & 0.0147 & 0.0254 \\
\hline Inflation Rate & 8.6127 & 2.6894 & 2.8423 & 14.2113 \\
\hline Interest Rate & 0.0723 & 0.0135 & 0.0600 & 0.1025 \\
\hline \multirow[t]{2}{*}{ Oil Prices } & 1.5516 & 0.6071 & 0.4946 & 3.2695 \\
\hline & \multicolumn{4}{|c|}{ CHINA } \\
\hline Market Returns & 0.0018 & 0.0857 & -0.2463 & 0.2057 \\
\hline Exchange Rate & 0.1524 & 0.0087 & 0.1303 & 0.1638 \\
\hline Inflation Rate & 2.912164 & 2.0773 & -1.7554 & 8.0059 \\
\hline Interest Rate & 0.0319 & 0.0035 & 0.0279 & 0.0414 \\
\hline Oil Prices & 12.0579 & 3.7312 & 5.1141 & 20.2946 \\
\hline
\end{tabular}

Table V Panel Regression for each BRIC economies

\begin{tabular}{|c|c|c|c|c|c|c|c|c|}
\hline \multirow[t]{2}{*}{$\begin{array}{l}\text { Variables } \\
\end{array}$} & \multicolumn{2}{|c|}{ BRAZIL } & \multicolumn{2}{|c|}{ RUSSIA } & \multicolumn{2}{|c|}{ INDIA } & \multicolumn{2}{|c|}{ CHINA } \\
\hline & Coefficient & Prob. & Coefficient & Prob. & Coefficient & Prob. & Coefficient & Prob. \\
\hline Exchange Rate & $\begin{array}{l}-0.0525 \\
(0.1825)\end{array}$ & 0.7739 & $\begin{array}{l}-3.3466 \\
(3.0555)\end{array}$ & 0.2757 & $\begin{array}{c}4.9001 \\
(4.9555)\end{array}$ & 0.3248 & $\begin{array}{c}0.1687 \\
(1.0301)\end{array}$ & 0.8702 \\
\hline Inflation Rate & $\begin{array}{l}-0.0047 \\
(0.0044)\end{array}$ & 0.2886 & $\begin{array}{l}-0.0046 \\
(0.0036)\end{array}$ & 0.2054 & $\begin{array}{l}-0.0017 \\
(0.0027)\end{array}$ & 0.5463 & $\begin{array}{l}-0.0071 \\
(0.0054)\end{array}$ & 0.1891 \\
\hline Interest Rate & $\begin{array}{l}-0.2405 \\
(0.3685)\end{array}$ & 0.5154 & $\begin{array}{c}0.3474 \\
(0.5166)\end{array}$ & 0.5026 & $\begin{array}{c}0.7278 \\
(0.8405)\end{array}$ & 0.3884 & $\begin{array}{l}-2.1222 \\
(3.0113)\end{array}$ & 0.4824 \\
\hline Oil Prices & $\begin{array}{l}-0.0008 \\
(0.0009)\end{array}$ & 0.3765 & $\begin{array}{c}0.0096 \\
(0.0212)\end{array}$ & 0.6515 & $\begin{array}{l}-0.0249 \\
(0.0205)\end{array}$ & 0.2265 & $\begin{array}{l}-0.0020 \\
(0.0028)\end{array}$ & 0.4839 \\
\hline R Squared & 0.04 & & 0.06 & & 0.07 & & 0.08 & \\
\hline Adjusted R-Squared & 0.00 & & 0.05 & & 0.06 & & 0.05 & \\
\hline F-Statistics & $1.23^{\circ}$ & & 0.71 & & 0.90 & & 2.73 & \\
\hline Prob. & 0.29 & & 0.58 & & 0.53 & & 0.03 & \\
\hline
\end{tabular}

Table VI Redundant Fixed Effects Tests

\begin{tabular}{lccc}
\hline \hline Effects Test & Statistic & d.f. & Prob. value \\
\hline \hline & 0.5280 & $(3,472)$ & 0.6632 \\
Cross-section F & 1.6081 & 3 & 0.6575 \\
\hline \hline
\end{tabular}

